\title{
VELETRHY A VÝSTAVY JAKO NÁSTROJ MARKETINGOVÉ KOMUNIKACE VYSOKÝCH ŠKOL
}

\section{Barbara Morská}

\section{Klíčová slova:}

Veletrhy, výstavy, podpora prodeje, public relations, cíle vystavovatele, výběr veletrhu.

\section{Key words:}

Trade fairs, exhibitions, sales promotion, public relations, exhibitor goals, trade fair selection.

\begin{abstract}
Abstrakt
V souvislosti s vývojem společnosti je nezbytné, aby i vzdělávací instituce efektivně komunikovaly se svými stávajícími i potenciálními zákazníky, veřejností a dalšími subjekty na trhu. V rámci marketingové komunikace mohou tyto instituce využívat různé nástroje, jedním z těchto nástrojů jsou veletrhy a výstavy. Článek se zabývá problematikou využívání veletrhů a výstav v rámci marketingové komunikace vysokých škol.
\end{abstract}

\begin{abstract}
Simultaneously with the development of society generally, it is essential for the educational institutions to communicate with current and potential customers, general public and all market players in a very efficient way, respecting all the developmental trends in the society. These institutions have a variety of marketing tools for their marketing communication at disposal. Trade fairs and exhibitions represent very significant tools. The article deals with the issues of trade fairs and exhibitions utilized in the marketing communications of high education institutions.
\end{abstract}

\section{Úvod}

Každá vzdělávací instituce - tedy i vysoké školy - je součástí marketingového prostředí, které ji ovlivňuje. Vzhledem $\mathrm{k}$ trendům, které je možné v jednotlivých částech marketingového prostředí identifikovat (změny $\mathrm{v}$ demografické struktuře obyvatelstva, konkurenční prostředí vzdělávacího trhu atd.), je nezbytné, aby vzdělávací instituce efektivně komunikovaly se svými zákazníky, veřejností a dalšími subjekty na trhu.

V rámci marketingové komunikace může vysoká škola využít jednotlivé nástroje tzv. komunikačního mixu. Jedná se především o osobní komunikaci pracovníků školy, vztahy $\mathrm{k}$ veřejnosti a $\mathrm{v}$ menší míře i reklamu [5]. Míra jejich využití závisí na následujících faktorech: cíle komunikace, cílová skupina, finanční možnosti, aktivity konkurence apod.

Jedním z nástrojů marketingové komunikace, které jsou vysokými školami ve velké míře využívány, jsou výstavy a veletrhy. Výstavnictví obecně představuje komplexní prezentaci výsledků práce subjektů nejrůznějších oborů. Výstavní akce mohou mít podle způsobu provedení řadu podob, a tím i označení. Prezentují se hospodářské, vědecko-technické, výzkumné či umělecké výsledky práce. Odlišují se nejen oborem prezentovaných subjektů, ale zejména geografickým dosahem akce a obchodním charakterem. [7] 


\section{Definice veletrhů a výstav a jejich postavení v komunikačním mixu}

Jednotná klasifikace a vymezení pojmu „,veletrhy a výstavy“ neexistuje. Veletrhy jsou definovány jako ekonomicky zaměřené akce, jejichž cílem je prezentace reálných exponátů, zatímco výstavní akce pak spíše propagují myšlenky a záměry různých subjektů společenského života. Pojmem výstava lze však označit i některé akce ekonomického charakteru. [7]

Pojmem „výstavy“ nebo „veletrhy“ je možné rovněž označit místo, kde se setkávají firmy produkující hmotné produkty nebo služby se svými zákazníky (stávajícími či potenciálními), dodavateli, veřejností, ale také konkurencí.

„Výstava“, není-li spojena s prodejem (prodejní výstava), je prezentací především výsledků umělecké, kulturně-výchovné, vědecko-technické, výzkumné, hospodářské, zájmové či jiné činnosti. Má především informativní, poznávací a vzdělávací zaměření, bývá určena nejširší veřejnosti. Její tematická orientace může být velmi široká. Lze říci, že převažuje neobchodní, nekomerční povaha (alespoň v prvním plánu), jejími organizátory bývají státní instituce, zájmové organizace, nevládní organizace, společenská hnutí, občanské iniciativy, soukromé osoby a firmy. Výstava trvá delší dobu, může měnit místo konání. [6]

U „veletrhư“ převažuje jasné komerční zaměření - posílení obchodních vztahů a hospodářské spolupráce. V obsahové orientaci konkrétních veletrhů dochází ke stále větší specializaci. Veletrh trvá obvykle několik dnů. Stejný tematický veletrh se může konat v průběhu roku na více místech. [6]

Z výše uvedených definic vyplývá, že veletrhy a výstavy lze v rámci komunikačního mixu zařadit nejen do podpory prodeje, ale také do public relations. Do oblasti podpory prodeje spadají vzhledem k úzké návaznosti na prodej (komerční zaměření). Do oblasti public relations pak z důvodu tvorby či posílení image. Posílení image bývá na takovýchto akcích jedním z hlavních cílů. Předností veletrhů a výstav je osobní kontakt mezi vystavovateli a velkým množstvím zákazníků. Jedná se nejen o prezentaci dané vysoké školy, studijních programů atd., ale také o okamžité získávání zpětné vazby - z tohoto pohledu je možné hovořit o osobní formě komunikace, osobním prodeji. Komunikační působení účasti na veletrhu nebo výstavě je možné umocnit využitím dalších komunikačních nástrojů reklamou, propagačními materiály atd.

\section{Klasifikace veletrhů a výstav}

Veletrhy a výstavy je možno klasifikovat podle různých hledisek. Některé z nich jsou následně uvedeny.

Z obchodního pohledu akce:

- komerční (prezentační akce produktů, služeb a poznatků firem a sdružení prezentovaných oborů, která může být prodejní, kontraktační či kombinací obou),

- nekomerční (akce převážně uměleckého, sběratelského a informačního typu, akce převážně dlouhodobého či putovního charakteru pořádané státními institucemi, společenskými hnutími nebo zájmovými společenstvími). [7] 
Dle geografického dosahu se dělí veletrhy a výstavy na:

- lokální,

- regionální,

- národní,

- kontinentální,

- mezinárodní. [7]

Oborové členění veletrhů je následující:

- všeobecný veletrh,

- víceoborový veletrh,

- jednooborový veletrh. [7]

Také na české veletržní scéně dochází v posledních letech $\mathrm{k}$ posilování pozice jednooborových veletrhů. Zatímco před deseti a více lety bylo trendem prezentovat co nejširší spektrum oborů na jednom místě, současným trendem se stávají oborově specializované akce. Velice důležitou podmínkou pro zdárný rozvoj jednooborových akcí zůstává stabilita a růst daného oboru. [7]

\section{Komunikační vazby na veletrzích a výstavách}

Základní komunikaci na veletrzích a výstavách lze znázornit níže uvedeným grafickým záznamem. Výchozí impuls dodávají organizátoři. Ti musí zajistit účast co největšího počtu nejvýznamnějších vystavovatelů a $\mathrm{k}$ dosažení tohoto cíle často využívají bandwagonový efekt. Jakmile se podaří získat některého z leaderů na dotyčném trhu, nabývá připravovaná akce na prestiži a atraktivitě. Úspěch veletrhu či výstavy nespočívá pouze v materiálních a ekonomických podmínkách, jež jsou organizátoři schopni nabídnout. Důležitějším aspektem je skutečnost, zda se celá akce stane významnou - tzn. kolik prestižních firem, a jakým způsobem, zde budou vystavovat, kolik kompetentních návštěvníků se zde dostaví, a jak se akci podaří prezentovat ve sdělovacích prostředcích. [1]

Obr. 1: Základní komunikační vazby na veletrzích a výstavách

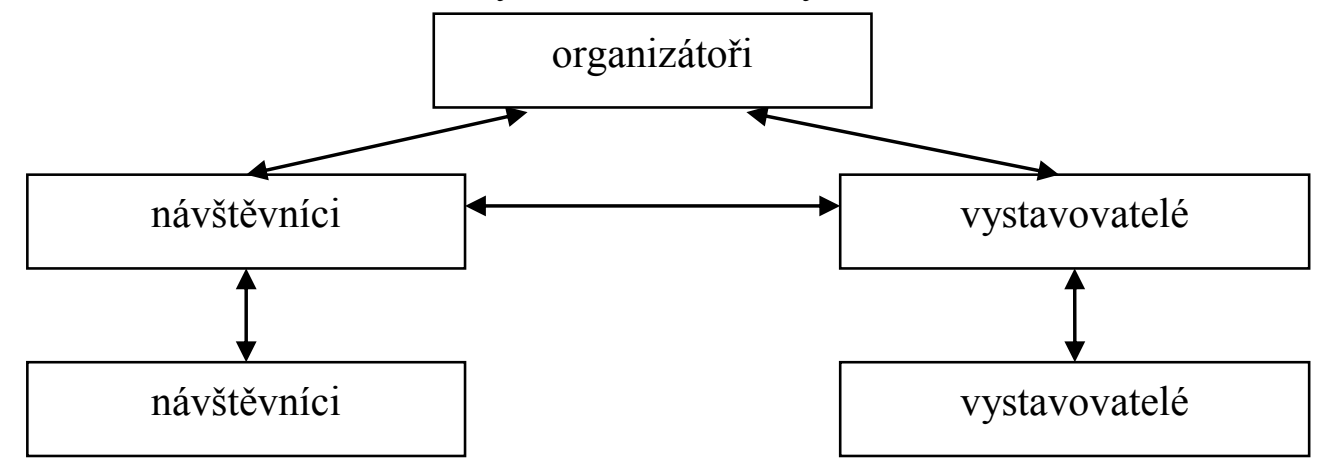

Zdroj: [1]

Je nutno připomenout, že pozornost by neměla být věnována pouze komunikaci organizátorů a vystavovatelů s návštěvníky, např. prostřednictvím sdělovacích prostředků, jelikož je nezanedbatelné, že mezi sebou komunikují také návštěvníci, v rámci doprovodného programu, na odborných semináŕích apod. K další formě komunikace dochází během 
setkávání vystavovatelů, kteří mezi sebou komunikují v rámci seznamování se s nabídkou konkurence, či domlouvání budoucí spolupráce, kooperace. [1]

\section{Proces př́ípravy účasti na veletrhu}

Pokud se vysoká škola rozhodne účastnit se veletrhu či výstavy, je nezbytné, aby akce stejně jako ostatní marketingové aktivity - byla řádně naplánovaná. Př́prava, samotná účast na veletrhu či výstavě a následné činnosti představují proces, sestávající se z následujících kroků. Prvním krokem vždy zůstává stanovení cílů, kterých by mělo být účastí na veletrhu či výstavě dosaženo.

Vystavovatel si obvykle stanoví více cílů z důvodu efektivního vynaložení nákladů spojených se zajištěním a účastí na veletrhu, např.:

- poskytnutí komplexních informací o nabídce možností studia na dané škole,

- představení novinek (např. nový studijní obor na vysoké škole) a zjišt'ování reakcí ze strany zákazníků,

- získání informací o potenciálních zákaznících, jejich preferencích, chování při výběru studia atd.,

- posílení povědomí školy,

- podpora image školy,

- získání nových informací o trhu,

- průzkum konkurence.

Veletrhy představují důležitou součást marketingových komunikací a patří k významnému informačnímu zdroji. Výsledky výzkumů sledujících důvody účasti vysokých škol na veletrzích ukazují na vzrůstající význam mimoekonomických ukazatelů: budování a péče o image, prezentaci firmy, zvýšení její známosti, sběr a výměna informací. [7]

Rovněž návštěvníci přicházejí na veletrh s určitými cíly. Studenti (př́íp. rodiče) si zde mohou vytvořit přehled o situaci na trhu vysokých škol, získat více informací týkající se konkrétních studijních oborů, získat podrobnější podklady, materiály pro další rozhodování. Výchovní poradci či pedagogové mohou získat ucelený přehled o aktuální situaci na trhu. Informace lze získat u stánků jednotlivých vystavovatelů nebo v rámci doprovodného programu, napřr. přednášek.

Teprve poté, jsou-li cíle řádně stanoveny, je možné definovat další kroky. Výběr veletrhu či výstavy je vždy realizován na základě určitých kritérií, např.:

- počet a profil návštěvníků,

- počet vystavovatelů,

- účast konkurentů,

- náklady na účast,

- doprovodný program,

- doba konání veletrhu,

- známost veletrhu,

- vlastní zkušenosti vystavovatele z předchozích ročníků nebo osobní návštěva dané akce. 
Důležitým vodítkem v procesu rozhodování o účasti jsou rovněž výsledky auditu, který objektivně posuzuje údaje o veletrhu, vykazované organizátory výstav a veletrhů. Hodnocení vychází ze standardů Unie mezinárodních veletrhů UFI a z praxe významných veletržních správ v zahraničí. V České republice byl odborný audit zaveden v roce 1996. Sledována je čistá výstavní plocha, počet vystavovatelů, počet dalších zastoupených firem, počet návštěvníků a počet akreditovaných novinářů. [7]

Potřebné informace o jednotlivých veletrzích je možné získat u pořadatelů akcí, významným zdrojem těchto informací je internet (www.veletrhy.cz nebo www.veletrhyavystavy.cz).

V rámci České republiky se mohou vysoké školy prezentovat na veletrhu Gaudeamus. Gaudeamus se koná od roku 1994 v Brně, vždy na přelomu října a listopadu, od roku 2008 se koná rovněž v Praze na výstavišti v Holešovicích. Veletrh je zaměřen na pomaturitní a celoživotní vzdělávání.

Jinou možností je akce „Učeň, stř̌edoškolák, vysokoškolák“, která se koná v Ostravě. Na rozdíl od veletrhu Gaudeamus je tato aktivita zaměřena na více cílových skupin.

Rostoucí význam internetu, stále častěji využívaného komunikačního média, vyvolal vznik tzv. virtuálních veletrhů. Porovnáním údajů v tabulce 1 však zjistíme, že „klasické“ veletrhy svou oblíbenost neztrácejí, ani ze strany českých vystavovatelů, ani ze strany českých návštěvníků.

Tab. 1: Vývoj počtu vystavovatelů, výstavní plochy a návštěvnosti veletrhu Gaudeamus v Brně

\begin{tabular}{|r|r|r|r|}
\hline Rok & $\begin{array}{r}\text { Počet } \\
\text { vystavovatelů }\end{array}$ & $\begin{array}{r}\text { plocha } \\
\text { v m}^{2}\end{array}$ & návštěvnost \\
\hline 1994 & 27 & 280 & 17000 \\
\hline 1995 & 31 & 320 & 17000 \\
\hline 1996 & 32 & 315 & 21500 \\
\hline 1997 & 30 & 378 & 19800 \\
\hline 1998 & 40 & 534 & 18700 \\
\hline 1999 & 42 & 474 & 13500 \\
\hline 2000 & 46 & 530 & 24600 \\
\hline 2001 & 59 & 669 & 23400 \\
\hline 2002 & 71 & 701 & 25830 \\
\hline 2003 & 77 & 705 & 28038 \\
\hline 2004 & 94 & 839 & 29161 \\
\hline 2005 & 99 & 960 & 29460 \\
\hline 2006 & 126 & 1109 & 27841 \\
\hline 2007 & 143 & 1295 & 30605 \\
\hline 2008 & 152 & 1393 & 30865 \\
\hline 2009 & 206 & 1556 & 32981 \\
\hline 2010 & 186 & 1925 & 30008 \\
\hline 2011 & 185 & 2000 & 30359 \\
\hline
\end{tabular}

Pozn: výstavní plocha uvedena bez zázemí vystavovatelů, skladových prostor, přednáškového sálu a prostor pro organizaci veletrhu

Zdroj: $[15,17]$

Pokles počtu vystavovatelů v roce 2010 byl zapříčiněn nižší účastí univerzit a vysokých škol z Číny a ostatních asijských zemí. 
Na veletrzích se jako vystavovatelé účastní univerzity, vysoké školy, jednotlivé fakulty, vyšší odborné školy a jiné vzdělávací nebo poradenské instituce, např. jazykové školy nebo agentury, instituce zajištující jazykové a jiné vzdělávání v zahraničí a instituce, které poskytují poradenství voblasti vzdělávání a přípravu na přijímací zkoušky. Mezi vystavovateli se objevují nakladatelství odborné literatury. Návštěvníci mají možnost získat poměrně komplexní představu o trhu pomaturitního a celoživotního vzdělávání. Strukturu vystavovatelů v Brně a Praze uvádí následující tabulky.

Tab. 2: Struktura vystavovatelů - Gaudeamus Brno

\begin{tabular}{|l|r|r|r|r|r|r|r|r|r|r|}
\hline & 2002 & 2003 & 2004 & 2005 & 2006 & 2007 & 2008 & 2009 & 2010 & 2011 \\
\hline $\begin{array}{l}\text { univerzity, vysoké školy } \\
\text { nebo samostatné } \\
\text { fakulty }\end{array}$ & 43 & 43 & 49 & 59 & 85 & 103 & 105 & 163 & 145 & 123 \\
\hline vyšší odborné školy & 12 & 14 & 20 & 13 & 19 & 20 & 19 & 18 & 19 & 21 \\
\hline $\begin{array}{l}\text { jiné vzdělávací } \\
\text { a poradenské instituce }\end{array}$ & 16 & 20 & 30 & 22 & 19 & 19 & 21 & 7 & 23 & 40 \\
\hline $\begin{array}{l}\text { nakladatelství odborné } \\
\text { literatury }\end{array}$ & $\mathrm{x}$ & $\mathrm{x}$ & $\mathrm{x}$ & 5 & 6 & 6 & 7 & 8 & 7 & 9 \\
\hline
\end{tabular}

Zdroj: $[8,9,10,11,12,13,14,15,16,17]$

Tab. 3: Struktura vystavovatelů - Gaudeuamus Praha

\begin{tabular}{|l|r|r|r|r|}
\hline & 2008 & 2009 & 2010 & 2011 \\
\hline $\begin{array}{l}\text { univerzity, vysoké školy } \\
\text { nebo samostatné fakulty }\end{array}$ & 54 & 72 & 113 & 113 \\
\hline vyšší odborné školy & 14 & 13 & 7 & 8 \\
\hline $\begin{array}{l}\text { jiné vzdělávací } \\
\text { a poradenské instituce }\end{array}$ & 21 & 16 & 20 & 31 \\
\hline
\end{tabular}

Zdroj: [18, 19, 20, 21]

Na veletrhu bývají zastoupeni také zahraniční vystavovatelé. Jejich počet a počet zemí je uveden v následující tabulce. Nejčastěji se veletrhu Gaudeamus účastní Slovensko, Německo, Rakousko, Velká Británie, Švýcarsko a Holandsko.

Tab. 4: Vývoj počtu vystavujících zemí a počtu vystavovatelů

\begin{tabular}{|l|r|r|r|r|}
\hline & \multicolumn{2}{|c|}{ Brno } & \multicolumn{2}{|c|}{ Praha } \\
\cline { 2 - 5 } & počet zemí & počet vystavovatelů & počet zemí & počet vystavovatelů \\
\hline 2002 & 3 & 3 & $\mathrm{x}$ & $\mathrm{x}$ \\
\hline 2003 & 2 & 2 & $\mathrm{x}$ & $\mathrm{x}$ \\
\hline 2004 & 7 & 16 & $\mathrm{x}$ & $\mathrm{x}$ \\
\hline 2005 & 7 & 13 & $\mathrm{x}$ & $\mathrm{x}$ \\
\hline 2006 & 11 & 28 & $\mathrm{x}$ & $\mathrm{x}$ \\
\hline 2007 & 11 & 33 & $\mathrm{x}$ & $\mathrm{x}$ \\
\hline 2008 & 12 & 38 & 13 & 28 \\
\hline 2009 & 11 & 81 & 8 & 13 \\
\hline 2010 & 16 & 54 & 15 & 23 \\
\hline 2011 & 14 & 47 & 13 & 26 \\
\hline
\end{tabular}

Zdroj: $[8,9,10,11,12,13,14,15,16,17,18,19,20,21]$

Co se týče struktury návštěvníků, převážnou většinu $(80-90 \%)$ tvoří studenti třetích a čtvrtých ročníků středních škol. Veletrhu Gaudeamus se účastní návštěvníci ze všech krajů České republiky. Vzhledem k místu konání veletrhu v Brně pochází největší počet 
návštěvníků z Jihomoravského, Moravskoslezského, Zlínského a Olomouckého kraje, $5 \%$ návštěvníků přijíždí ze Slovenska. Nejvíce návštěvníků veletrhu v Praze pochází z Prahy a Středočeského kraje.

Zájem studentů o studijní obory uvádí následující tabulka. Největší zájem zaznamenávají společenské vědy, ekonomické obory, management a jazykovědné obory.

Tab. 5: Zájem studentů o studijní obory (v \%)

Zdroj: $[15,21]$

\begin{tabular}{|l|r|r|}
\hline & $\begin{array}{r}\text { Praha } \\
2011\end{array}$ & \multicolumn{1}{|c|}{$\begin{array}{l}\text { Brno } \\
2009\end{array}$} \\
\hline společenské vědy & $35 \%$ & $22 \%$ \\
\hline ekonomický obor & $24 \%$ & $22 \%$ \\
\hline management & $27 \%$ & $18 \%$ \\
\hline prírodovědný obor & $13 \%$ & $13 \%$ \\
\hline právnický obor & $19 \%$ & $12 \%$ \\
\hline jazykovědný obor & $27 \%$ & $10 \%$ \\
\hline technický obor & $12 \%$ & $18 \%$ \\
\hline umělecký obor & $14 \%$ & $7 \%$ \\
\hline medicínský obor & $13 \%$ & $14 \%$ \\
\hline učitelský obor & $13 \%$ & $11 \%$ \\
\hline informatika & $10 \%$ & $10 \%$ \\
\hline sportovní & $9 \%$ & $7 \%$ \\
\hline jiný obor & $5 \%$ & $5 \%$ \\
\hline $\begin{array}{l}\text { matematicko-fyzikální } \\
\text { obor }\end{array}$ & $8 \%$ & $5 \%$ \\
\hline
\end{tabular}

Návštěvníci veletrhu Gaudeamus projevují největší zájem o bakalářské studium s možností pokračování (cca 50 - 58 \%), a následně o magisterské navazující studium.

Mezi kritéria zvažovaná vystavovatelem pro výběr konkrétního veletrhu patří, jak již bylo uvedeno, náklady související s účastí na veletrhu. Každý vystavovatel, kterému je přidělena expozice, je povinen uhradit registrační poplatek (výše poplatku není závislá na velikosti expozice), registrační poplatek činil v roce 20111300 Kč (Gaudeamus Brno), resp. 1000 Kč (Gaudeamus Praha), ceny jsou uvedeny bez DPH.

Další náklady souvisí s pronájmem výstavní plochy. Cena pronájmu výstavní plochy vč. postavení konstrukce expozice (pokud ji zajišt'uje organizátor veletrhu) činí $2750 \mathrm{Kč} / \mathrm{m}^{2}$ (bez DPH). Pokud si výstavbu expozice zajišt'uje vystavovatel, platí tento pouze za pronájem výstavní plochy, a to $2500 \mathrm{Kč} / \mathrm{m}^{2}$ (bez DPH). Ceny za pronájem výstavní plochy zůstávají na stejné výši od roku 2008.

Organizátor veletrhu nabízí vystavovatelům další služby, které se týkají vybavení expozice, vystoupení v rámci přednášek na veletrhu a dalších možností propagace (katalog, prezentace na webu, rozesílání propagačních materiálů středním školám a učilištím) apod. Ceny služeb a jejich detailnější popis, jsou uvedeny v objednávkovém formuláři veletrhu.

K těmto nákladům je nutné připočíst další náklady spojené s postavením expozice (při zajištění externím dodavatelem), náklady na propagační materiály rozdávané návštěvníkům 
veletrhu (letáky, brožurky, reklamní předměty), náklady spojené s personálním zajištěním veletrhu (např. cestovné, ubytování) apod.

Přípravu na účast na veletrhu je třeba vést na třech základních úrovních - personální, technické a marketingové. Veletržní účast firmy se musí vyznačovat celkovým souladem stánku s vystavenými exponáty, chováním, jednáním a kulturou personálu, všemi výrazovými prvky jednotného vizuálního stylu. Zákazník vnímá vše jako celek, jedině takto lze formovat „corporate image“ vystavující společnosti. [6]

Je nezbytné stanovit, kdo, v rámci vysoké školy, bude odpovědný za přípravu a účast na veletrhu. Obvykle to bývá oddělení pro vnější vztahy (veřejnost, média), resp. manažer pro vnější vztahy (komunikaci), jejichž úkolem je prezentace vysoké školy navenek a komunikace $\mathrm{s}$ veřejností. Do kompetencí oddělení či manažera spadá prríprava aktivit $\mathrm{s}$ cílem zviditelnění vysoké školy, často formou účasti na veletrhu. Při přípravě účasti vysoké školy na veletrhu je nezbytná spolupráce s ostatními odděleními dané instituce.

\section{Doprovodné programy jako další možnost komunikace s cílovým trhem}

Účast na veletrhu v pozici vystavovatele je obvykle poměrně nákladná, proto je $\mathrm{v}$ zájmu firmy, aby vynaložené prostředky přinesly co největší efekt ve formě posílení image firmy, její známosti na cílovém trhu nebo navázání nových kontaktů. Je proto vhodné, kromě samotného veletržního stánku, zvážit i další související komunikační aktivity, které mohou pomoci komunikační cíle naplnit. V podstatě všechny velké veletrhy nabízejí množství dalších př́íležitostí, jak firmu a její produkty prezentovat i mimo veletržní stánek, a to formou seminářů, workshopů, panelových diskusí, tiskových konferencí, společenských akcí apod. konaných v prostorách výstaviště. Jejich výhodou je osobnější kontakt s návštěvníky veletrhu často v méně formální atmosféře. [3]

Doprovodný program veletrhu Gaudeamus tvoří přenášky, konané po všechny dny veletrhu. Jednotliví vystavovatelé mohou ještě více upozornit na svou účast na veletrhu, prezentovat možnosti studia a účinněji vyzvat návštěvníky k návštěvě svého stánku. Přednášek se účastní kolem $20 \%$ návštěvníků veletrhu. Výjimku tvořil rok 2010 v Brně, kdy se přenášek zúčastnilo $31 \%$ návštěvníků. Návštěvníci přednášek obvykle vyplňují slosovatelné kupóny, následně je vylosováno pět návštěvníků, kteří jsou odměněni věcnými cenami s logem veletrhu nebo konkrétní vysoké školy.

V roce 2008 byl v Brně uveden nový doprovodný program „Věda pro život“. Cílem je prezentace výsledků vědecké činnosti univerzit a vysokých škol a jejich uplatnění v praxi. Součástí jsou i praktické ukázky. V roce 2008 do tohoto doprovodného programu vstoupily Mendelova zemědělská a lesnická univerzita v Brně, Univerzita obrany a Vysoké učení technické v Brně. Zájem o doprovodný program ze stran vystavujících institucí roste. V roce 2009 se v doprovodném programu prezentovala Mendelova zemědělská a lesnická univerzita v Brně, Univerzita obrany, Univerzita Tomáše Bati ve Zlíně, Vysoká škola báňská technická univerzita Ostrava, ŠKODA AUTO a.s., vysoká škola, Vysoká škola chemickotechnologická v Praze, Vysoké učení technické v Brně, fakulta elektrotechniky a komunikačních technologií a fakulta strojního inženýrství.

V roce 2010 se v doprovodném programu prezentovala Mendelova zemědělská a lesnická univerzita v Brně, Univerzita Karlova v Praze a Univerzita obrany v Brně (technicky 
zaměřeným vysokým školám slouží nová expozice). V roce 2011 byla zmíněná trojice českých univerzit doplněna zahraničním vystavovatelem EF Education First.

Od roku 2010 se mohou technicky zaměřené vysoké školy prezentovat v rámci doprovodných programů v expozici s názvem „Pojd'me si hrát s technikou“. Cílem je propagace studia na technicky zaměřených oborech. Expozice se účastní České vysoké učení technické v Praze, Technická univerzita v Liberci, Univerzita Pardubice, Vysoká škola báňská - Technická univerzita Ostrava, Vysoká škola chemicko-technologická v Praze, Vysoké učení technické v Brně a Západočeská univerzita v Plzni.

Součástí doprovodného programu je rovněž soutěž o nejlepší expozici, která probíhá v Brně od roku 2009. Hodnotící komise je tvořena studenty (Obchodní akademie a VOŠ obchodní v Brně, Střední škola umění a designu v Brně, Střední průmyslová škola technická v Brně, studenti nominovaní vystavovateli). Studenti hodnotí kvalitu prezentací škol, množství a srozumitelnost poskytovaných informací, zájem o studenty. Výsledky soutěže jsou vyhlašovány na společenském večeru.

\section{Jiné možnosti komunikace na veletrhu}

Vystavovatelé mohou využít $\mathrm{k}$ propagaci vlastních institucí tištěný katalog a podrobný katalog na $\mathrm{CD}$, které obdrží každý návštěvník veletrhu. Katalogy obsahují podrobné informace o nabídce vzdělávání na vystavujících školách a vzdělávacích institucích. V tištěném katalogu i katalogu na CD může každý vystavovatel zdarma uvést základní informace v následujícím rozsahu: název instituce, poštovní adresa, telefonní a faxová čísla, adresa e-mail a internetové stránky. Vystavující škola může v katalogu uvést i další informace (informace o fakultách a studijních oborech, kontakty na studijní oddělení, informace o přijímacím řízení apod.). Na CD jsou navíc zpracovány interaktivní rejstříky studijních oborů, zvlášt' pro české a zvlášt' pro zahraniční školy. Názvy škol v seznamu jsou propojeny na základní nebo rozšířené informace o škole. Katalog na $C D$ obsahuje také slovníček vysokoškolských pojmů.

Informační stánek slouží jako bezplatný poradenský servis pro studenty. Pomáhá s vyhledáváním studijních oborů, fakult, vysokých škol. Informační stánek dává v podstatě odpovědi na otázky:

- Kam po maturitě?

- Kde studovat určitý obor?

- Které obory lze studovat na určité škole?

- Kde studovat určitou fakultu?

Veškeré informace o veletrhu jsou dostupné na internetové adrese www.gaudeamus.cz. Standardně jsou zde po skončení veletrhu zveřejňovány i základní kontaktní údaje na vystavující školy, rejstř́ky studijních oborů a seznamy škol s uvedením studijních oborů. Služba je poskytována organizátorem veletrhu vystavujícím školám zdarma. V sekci „Pro studenty“ je uveden na www.gaudeamus.cz „Slovníček vysokoškolských pojmü“, „Průvodce budoucího vysokoškoláka“ a rejstřík zemí s uvedením podmínek studia v každé uvedené. V následujícím grafu je uveden vývoj počtu př́stupů (sledováno od února 2002) na webovou stránku veletrhu. 
Graf 1: Vývoj počtu př́stupů na www.gaudeamus.cz

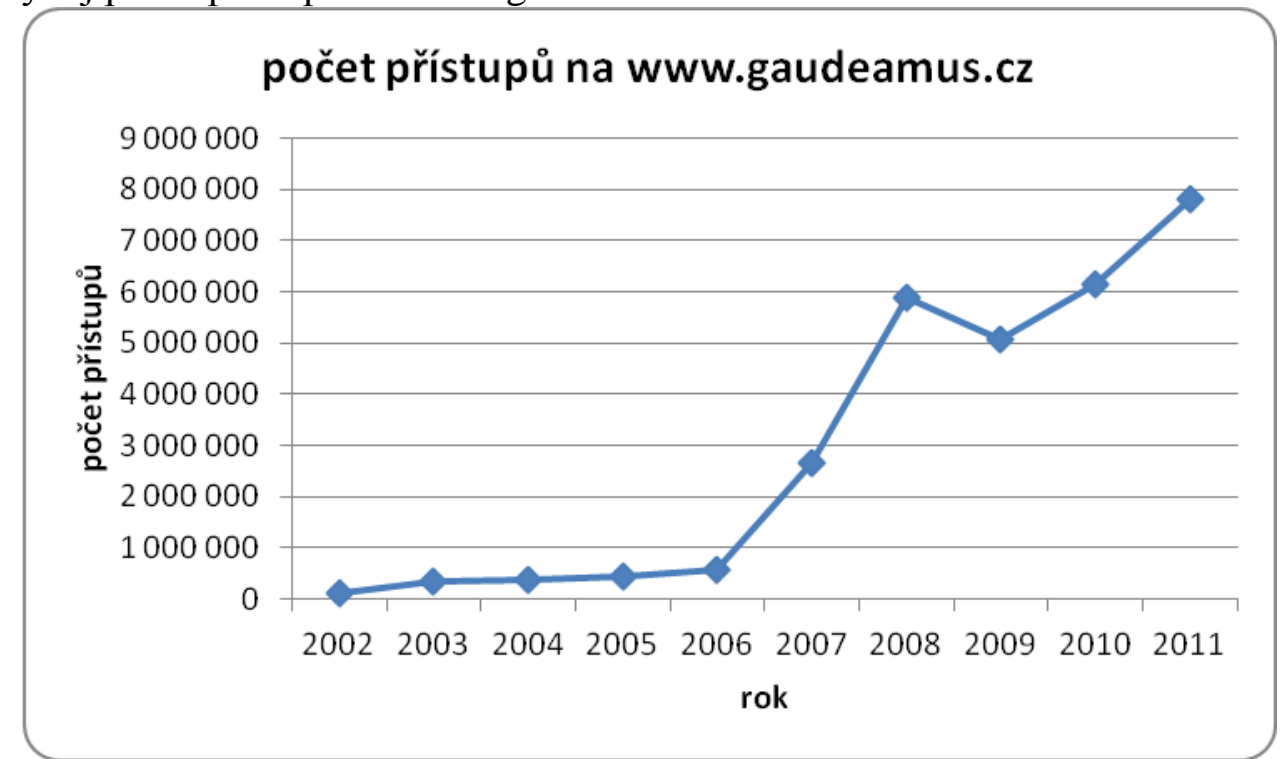

pozn: v roce 2009 nejsou uvedeny hodnoty za listopad a prosinec, v letech 2010 a 2011 nejsou uvedeny hodnoty za prosinec

Zdroj: $[15,21]$

Největší počet prŕístupů je zaznamenán každoročně v měsíci říjnu, v období před konáním veletrhu.

\section{Zhodnocení efektivnosti účasti na veletrhu}

Po ukončení účasti na výstavě nebo veletrhu je nutné vyhodnotit efektivnost, tzn. porovnat dosažené výsledky s cíli. Jak ukazují výzkumy, problém vyhodnocení účinnosti veletržní účasti firem spočívá především ve skutečnosti, že si většina vystavovatelů není schopna stanovit před veletrhem prokazatelné cíle [6].

Kritéria hodnocení míry efektivity a úspěšnosti účasti na veletrhu vyplývají z cílů a jejich správného stanovení (dle pravidla SMART). Návaznost jednotlivých možností marketingové komunikace na veletrzích na definované cíle je uvedena v př́loze č. 1 .

Po skončení veletrhu by měla být zpracována zpráva o průběhu veletrhu a veletrh by měl být zhodnocen $\mathrm{z}$ hlediska naplnění stanovených cílů. Na této činnosti by se měli podílet všichni, kdo se podíleli na př́pravě veletrhu a kdo se veletrhu přímo účastnili, at' už přítomností na výstavním stánku a komunikací s návštěvníky nebo sběrem informací o konkurenci apod.

Je nutno také zohlednit skutečnost, že se efekty účasti na veletrhu zpravidla neprojevují okamžitě, ale s určitým časovým zpožděním. V př́ípadě vysokých škol je to ovlivněno termínem konání veletrhu a termíny prijímacích řízení na jednotlivých školách. V rámci přijímacího řízení je však možné realizovat anketu, jejímž cílem bude zjistit informační zdroje, na jejichž základě se studenti rozhodují o výběru oboru, resp. konkrétní vysoké školy.

K hodnocení efektivnosti účasti na veletrzích existuje řada metod, např̀.

- sledování množství rozdaného informačního materiálu,

- sledování počtu návštěvníků stánku, 
- pozorování chování návštěvníků,

- dotazování návštěvníků stánku. [4]

Osobní kontakt s návštěvníky dává jedinečnou př́ležitost nejen na ně působit, ale také získat řadu důležitých informací o své cílové skupině, o veřejnosti navštěvující daný veletrh, ale také o sobě a své firmě. Veletrhy jsou ideálním místem pro získání zpětné vazby, proto je důležité s touto př́ležitostí počítat a připravit se na ni. Řadu marketingových výzkumů mezi návštěvníky i vystavovateli veletrhu provádí pravidelně sami pořadatelé nebo je zadávají specializovaným agenturám. Výstupy jsou mnohdy pořadateli zveřejňované, zpravidla však ty části, které přinášejí upotřebitelné informace pro potenciální vystavovatele a pozitivně přispívají k propagaci veletrhu. [6]

Na webových stránkách veletrhu Gaudeamus jsou uváděny závěrečné zprávy z jednotlivých ročníků. Součástí zprávy jsou výsledky výzkumů realizovaných v průběhu veletrhu.

- výzkum mezi návštěvníky přednášek, jehož cílem je zjistit strukturu návštěvnosti dle cílových skupin, regionální rozložení návštěvnosti, zájem o studijní obory, o typ dalšího studia a význam vlivů při volbě dalšího studia (realizován od roku 2004),

- podrobnější výzkum, jehož cílem je zjistit detailnější informace o cílové skupině návštěvníků (respondenty jsou návštěvníci do 25 let).

Z výzkumů realizovaných v Praze (375 respondentů v roce 2010, 378 respondentů v roce 2011), plynou, mimo jiné, následující informace:

- většina respondentů studuje v době konání výzkumu na gymnáziu nebo střední odborné škole,

- většina respondentů se rozhodla pro účast na veletrhu sama,

- zdrojem prvotní informace je výchovný poradce ve škole, doporučení přátel či webové stránky veletrhu,

- $99 \%$ respondentů přijelo na veletrh s cílem hledat budoucí studium, většina respondentů přijela na veletrh hledat konkrétní studijní obor nebo školu,

- většina respondentů má zájem studovat v zahraničí, největší zájem je o studium v Anglii, USA a Německu. [20, 21]

\section{Závěr}

Veletrhy a výstavy patř́ mezi nástroje komunikačního mixu využívané vysokými školami ke komunikaci se svými zákazníky a veřejností.

Pro zajištění efektivity prezentace na veletrhu či výstavě si musí každý vystavovatel nejprve stanovit cíle, kterých chce svou účastí na veletrhu či výstavě dosáhnout. Dalším krokem je výběr veletrhu dle určitých kritérií (počet a struktura vystavovatelů, počet a struktura návštěvníků, náklady na účast atd.). Statistiky zpracovávané organizátory veletrhů mohou ovlivnit toto rozhodování.

Př́pravu na účast na veletrhu je třeba vést na třech základních úrovních - personální, technické a marketingové.

Vystavovatelé mohou komunikovat $\mathrm{s}$ cílovými skupinami v rámci svého stánku, účastí na doprovodném programu, formou inzerce v katalogu veletrhu, webových stránkách atd.

Po ukončení veletrhu je nezbytné provést analýzu efektivnosti účasti na veletrhu. 


\section{Literatura:}

[1] FORET, M. Marketingová komunikace. Brno: Computer Press, 2006. ISBN 80-2511041-9.

[2] HRADISKÁ, E., LETOVANCOVÁ, E. Psychologie marketingových komunikací. Brno: Vysoké učení technické v Brně, Fakulta technologická ve Zlíně, 1999. ISBN 80-2141421-9.

[3] KARLÍČEK, M., KRÁL, P. Marketingová komunikace. Jak komunikovat na našem trhu. Praha: Grada, 2011. ISBN 978-80-247-3541-2.

[4] DE PELSMACKER, P., GEUENS, M., VAN DEN BERGH, J. Marketingová komunikace. Praha: Grada Publishing, 2003. ISBN 80-247-0254-1.

[5] SVĚTLÍK, J. Marketing školy. Zlín: EKKA, 1996. ISBN 80-902200-8-8.

[6] SVOBODA, V., FORET, M., KOLÁŘOVÁ, K., ZUMROVÁ, L. Vystavujeme na veletrhu. Brno: Computer Press, 2002. ISBN 80-7226-645-4.

[7] VYSEKALOVÁ, J., HRUBALOVÁ, M., GIRGAŠOVÁ, J. Veletrhy a výstavy. Efektivní prezentace pro úspěšný prodej. Praha: Grada Publishing, 2004. ISBN 80-2470894-9.

\section{Elektronické zdroje:}

[8] Ohlédnutí za IX. ročníkem - Gaudeaumus ${ }^{\circledR}$ 2002. Gaudeamus ${ }^{\circledR}:$ Evropský veletrh celoživotního a pomaturitního vzdělávání [online]. Brno: MP - Soft a.s., C 2010. [cit. 16.3.2011]. Dostupné z: http://www.gaudeamus.cz/?id=vystavovatele/ gaudeamus10b\&mf $=5006166$

[9] Gaudeamus ${ }^{\circledR}$ 2003. Veletrh pomaturitního vzdělávání Gaudeamus ${ }^{\circledR}$ 2003. Brno 21. až 24. října 2003. Gaudeamus ${ }^{\circledR}:$ Evropský veletrh celoživotního a pomaturitního vzdélávání [online]. Brno: MP - Soft a.s., C 2010. Datum publikování 24. 10. 2003. [cit. 16.3.2011]. Dostupné $\quad \mathrm{z}: \quad \mathrm{http}: / / \mathrm{www}$.gaudeamus.cz/?id=vystavovatele/ gaudeamus10b\&mf $=5006165$

[10] Gaudeamus ${ }^{\circledR}$ 2004. Veletrh pomaturitního celoživotního vzdělávání Gaudeamus ${ }^{\circledR}$ 2004. Brno 19. až 22. ř́ina 2004. Gaudeamus ${ }^{\circledR:}$ Evropský veletrh celoživotního a pomaturitního vzdělávání [online]. Brno: MP - Soft a.s., (C) 2010. Datum publikování 22. 10. 2004. [cit. 16.3.2011]. Dostupné z: http:// www.gaudeamus.cz/?id=vystavovatele/gaudeamus10b\&mf=5006164

[11] MIKULA, P. Gaudeamus ${ }^{\circledR}$ 2005. Evropský veletrh pomaturitního celoživotního vzdělávání Gaudeamus® 2005. Brno 1. až 4. listopadu 2005. Gaudeamus ${ }^{\circledR: ~ E v r o p s k y ́ ~}$ veletrh celoživotního a pomaturitního vzdělávání [online]. Brno: MP - Soft a.s., (C) 2010. Datum publikování 6. 12. 2005. [cit. 16.3.2011]. Dostupné z: http://www.gaudeamus.cz/?id=vystavovatele/ gaudeamus 10b\&mf=5006163

[12] MIKULA, P. Gaudeamus ${ }^{\circledR}$ 2006. Evropský veletrh pomaturitního celoživotního vzdělávání Gaudeamus ${ }^{\circledR}$ 2006. Brno 31. října až 3. listopadu 2006. Gaudeamus ${ }^{\circledR}$ : Evropský veletrh celoživotního a pomaturitního vzdělávání [online]. Brno: MP Soft a.s., (C) 2010. Datum publikování 11. 12. 2006. [cit. 16.3.2011]. Dostupné z: http://www.gaudeamus.cz/?id=vystavovatele/ gaudeamus $10 \mathrm{~b} \& \mathrm{mf}=5006162$

[13] MIKULA, P. Gaudeamus ${ }^{\circledR}$ 2007. Evropský veletrh pomaturitního celoživotního vzdělávání Gaudeamus ${ }^{\circledR}$ 2007. Brno 30. října až 2. listopadu 2007. Gaudeamus ${ }^{\circledR}$ : Evropský veletrh celoživotního a pomaturitniho vzdělávání [online]. Brno: MP - Soft a.s., (C) 2010. Datum publikování 6. 12. 2007. [cit. 16.3.2011]. Dostupné z: http://www.gaudeamus.cz/?id=vystavovatele/ gaudeamus10b\&mf $=5006161$

[14] HONZÍK, M. J., MIKULA, P. Gaudeamus ${ }^{\circledR}$ 2008. Evropský veletrh pomaturitního celoživotního vzdělávání Gaudeamus ${ }^{\circledR}$ 2008. Brno 21. až 24. ř́ína 2008. Gaudeamus ${ }^{\circledR}$ : Evropský veletrh celoživotního a pomaturitního vzdělávání [online]. Brno: MP Soft a.s., 
(C) 2010. Datum publikování 1. 12. 2008. [cit. 16.3.2011]. Dostupné z: http://www.gaudeamus.cz/?id=vystavovatele/ gaudeamus 10b\&mf =5006160

[15] HONZÍK, M. J., MIKULA, P. Gaudeamus ${ }^{\circledR}$ 2009. Evropský veletrh pomaturitního celoživotního vzdělávání Gaudeamus ${ }^{\circledR}$ 2009. Brno 20. až 23. ř́́jna 2009. Gaudeamus ${ }^{\circledR}$ : Evropský veletrh celoživotniho a pomaturitního vzdělávání [online]. Brno: MP Soft a.s., (C) 2010. Datum publikování 20. 11. 2009. [cit. 16.3.2011]. Dostupné z: http://www.gaudeamus.cz/?id=vystavovatele/ gaudeamus $10 \mathrm{~b} \& \mathrm{mf}=5006159$

[16] HONZÍK, M. J., MIKULA, P. Gaudeamus ${ }^{\circledR}$ 2010. Evropský veletrh pomaturitního celoživotního vzdělávání Gaudeamus ${ }^{\circledR}$ 2010. Brno 2. až 5. listopadu 2010. Gaudeamus ${ }^{\circledR}$ : Evropský veletrh celoživotního a pomaturitního vzdělávání [online]. Brno: MP Soft a.s., C 2010. Datum publikování 3. 12. 2010. [cit. 16.3.2011]. Dostupné z: http://www.gaudeamus.cz/?id=vystavovatele/ gaudeamus10b\&mf $=5006158$

[17] HONZÍK, M. J., MIKULA, P. Gaudeamus ${ }^{\circledR}$ 2011. Evropský veletrh pomaturitního a celoživotního vzdělávání Gaudeamus ${ }^{\circledR}$ 2011. Brno 1. až 4. listopadu 2011. Gaudeamus ${ }^{\circledR}:$ Evropský veletrh celoživotního a pomaturitního vzdělávání [online]. Brno: MP Soft a.s., (C) 2011. Datum publikování 8. 12. 2011. [cit. 2.3.2012]. Dostupné z: http://www.gaudeamus.cz/ ?id=vystavovatele\%2Fgaudeamus11b\&mf=5006173

[18] MIKULA, P. Gaudeamus ${ }^{\circledR}$ region Praha 2008. Gaudeamus ${ }^{\circledR}$ International 2008. Veletrhy pomaturitního a celoživotního vzdělávání, I. ročník, Praha 9. - 10. dubna 2008. Závěrečná zpráva. Gaudeamus ${ }^{\circledR}$ : Evropský veletrh celoživotního a pomaturitního vzdělávání [online]. Brno: MP Soft a.s., (C) 2010. Datum publikování 30. 5. 2008. [cit. 16.3.2011]. Dostupné $\quad \mathrm{z}$ : http://www.gaudeamus.cz/ ?id=vystavovatele/gaudeamusip\&mf $=5013193$

[19] HONZÍK, M. J., MIKULA. P. Gaudeamus® region Praha 2009. Gaudeamus® International 2009. Veletrh pomaturitního a celoživotního vzdělávání, II. ročník, Praha 27. - 28. ledna 2009. Závěrečná zpráva. Gaudeamus ${ }^{\circledR:}$ Evropský veletrh celoživotního a pomaturitního vzděláváni [online]. Brno: MP Soft a.s., (C) 2010. Datum publikování 17. 2. 2009. [cit. 16.3.2011]. Dostupné z: http://www.gaudeamus.cz/ ?id=vystavovatele/gaudeamusip\&mf $=5013192$

[20] HONZÍK, M. J., MIKULA. P. Gaudeamus ${ }^{\circledR}$ Praha 2010. Veletrh pomaturitního a celoživotního vzdělávání, III. ročník, Praha 26. - 27. ledna 2010. Závěrečná zpráva. Gaudeamus ${ }^{\circledR}$ : Evropský veletrh celoživotního a pomaturitního vzdělávání [online]. Brno: MP Soft a.s., C 2010. Datum publikování 25. 2. 2010. [cit. 16.3.2011]. Dostupné z: http://www.gaudeamus.cz/?id=vystavovatele/ gaudeamusip\&mf=5013191

[21] HONZÍK, M. J., MIKULA. P. Gaudeamus ${ }^{\circledR}$ Praha 2011. Veletrh pomaturitního a celoživotního vzdělávání, IV. ročník, Praha 25. - 26. ledna 2011. Závěrečná zpráva. Gaudeamus ${ }^{\circledR}:$ Evropský veletrh celoživotního a pomaturitního vzdělávání [online]. Brno: MP Soft a.s., (C) 2011. Datum publikování 25. 2. 2011. [cit. 16.3.2011]. Dostupné z: http://www.gaudeamus.cz/?id=vystavovatele/ gaudeamusip\&mf=5013190

Klasifikace JEL: I23, M31

\section{Ing. Barbara Morská}

studentka doktorského studia

Obchodně podnikatelská fakulta v Karviné

Slezská univerzita v Opavě 
Př́loha č. 1 - Návaznost jednotlivých možností marketingové komunikace na veletrzích na definované cíle

Expozice

- prostřednictvím komunikace s návštěvníky veletrhu je naplňován cíl poskytování komplexních informací o nabídce možností studia na vysoké škole, zároveň je možné představit novinky, dále mohou zástupci vystavovatele získávat informace 0 potenciálních zákaznících (záměrech, způsobu rozhodování apod.)

- způsob prezentování a vystupování zástupců vystavovatele má také vliv na image školy, tím jak působí na své okolí (návštěvníky, ostatní vystavovatele, organizátory)

- zároveň tak vystavovatel poskytuje informace svým konkurentům

Přednášky v rámci doprovodných programů

- tuto formu veletržní marketingové komunikace je možné využít k základnímu představení vysoké školy, zejména však $\mathrm{k}$ představení novinek a tím také posílit povědomí o vysoké škole a její pozitivní image

Doprovodné programy „Věda pro život" a „Pojd’me si hrát s technikou“

- jsou vhodné pro představení novinek

- vzhledem k zaměření doprovodných programů lze touto formou podat komplexní informace o studiu na dané vysoké škole potenciálním studentům

- prezentací výsledků vědecké a výzkumné činnosti jednotlivých vysokých škol je možné pozitivně posílit image vysoké školy a zvýšit povědomí o ní u veřejnosti

Soutěž o nejlepší expozici

- vzhledem k zaměření - hodnotí se prezentování vysoké školy na veletrhu, srozumitelnost poskytovaných informací a zájem o studenty - je naplněn cíl posílení povědomí o vysoké škole a její image

Katalogy - tištěný a CD

- jsou k dispozici pro každého návštěvníka veletrhu - tím, že vysoká škola využije možnost zveřejnit $\mathrm{v}$ katalogu informace o své nabídce - směřuje k naplnění cíle poskytování komplexních informací, je možné zde představit novinky

Infostánek

- představuje bezplatný poradenský servis pro návštěvníky veletrhu - tím, že jsou zodpovězeny otázky ohledně možností studia - zvýší se tak povědomí o vysoké škole

Webové stránky veletrhu

- spojuje komunikační možnosti výše uvedených forem veletržní marketingové komunikace (kromě osobního kontaktu)

- výhodou je možnost přístupu $\mathrm{k}$ informacím na webu bez časového omezení 